\title{
Campur Kode pada Papan Reklame Iklan Komersial
}

\author{
Idham Maulana ${ }^{1)}$ \\ Universitas Indraprasta PGRI \\ Jalan Nangka No. 58 C/TB. Simatupang, Tanjung Barat, Jakarta Selatan 12530 \\ Hilda Hilaliyah $\left.{ }^{2}\right)$ \\ Universitas Indraprasta PGRI \\ Jalan Nangka No. 58 C/TB. Simatupang, Tanjung Barat, Jakarta Selatan 12530 \\ Bambang Sumadyo ${ }^{3)}$ \\ Universitas Indraprasta PGRI \\ Jalan Nangka No. 58 C/TB. Simatupang, Tanjung Barat, Jakarta Selatan 12530 \\ maulanaidam20@gmail.com ${ }^{1)}$
}

\begin{abstract}
The purpose of this study was to determine the form of mixed code in the form of words, phrases and clauses contained in comercial advertisment billboards and their implications for learning Indonesian. This type of research is descriptive qualitative research. The research technique used is the content analysis technique in comercial advertisement board sentence. analysis of the data used classifies the data contained in mixed codes such as word, phrases, and clues. The data used in this study were 52 mixed codes contained in comercial advertisment billboards. The results of this study, identified that there are findings of code mix in form of words as many as 22 findings (42.3\%), mixed codes in the form of phrases as many as 21 findings (40.4\%), mix codes in the form of clauses as many as 9 findings (17.3\%). Thus, the results of the dominant billboard findings are mixed code in word form.
\end{abstract}

Keyword: Mix Code, Billbooards, Comercial Advertising

\begin{abstract}
Abstrak
Tujuan dalam penelitian ini untuk mengetahui wujud campur kode yang berupa sisipan kata, frasa, dan klausa yang terdapat di dalam papan reklame iklan komersial dan implikasinya terhadap pembelajaran bahasa Indonesia. Jenis penelitian termasuk penelitian deskriptif kualitatif. Teknik penelitian yang digunakan adalah teknik analisis isi pada kalimat papan reklame iklan komersial. Analisis data yang digunakan mengklasifisikan data yang terdapat campur kode berupa, kata, frasa, dan klaua. Data yang digunakan dalam penelitian ini sebanyak 52 Campur kode yang terdapat dalam papan reklame iklan komersial. Hasil penelitian ini, teridentifikasi bahwa terdapat temuan Campur kode dalam bentuk kata sebanyak 22 temuan (42.3\%), Campur kode dalam bentuk frasa sebanyak 21 temuan (40.4\%), Campur kode dalam bentuk klausa sebanyak 9 temuan $(17.3 \%)$. Dengan demikian, hasil dari temuan papan reklame yang dominan adalah campur kode dalam bentuk kata.
\end{abstract}

Kata Kunci: Campur Kode, Papan Reklame, Iklan Komersial.

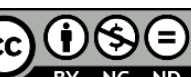

Creative Commons Attribution-NonCommercial-NoDerivatives 4.0 International License 


\section{PENDAHULUAN}

Bahasa menjadi salah satu bentuk dalam berkomunikasi sosial yang dipakai oleh setiap warga negara. Dalam suatu masyarakat, bahasa digunakan sebagai alat untuk menjalin hubungan untuk berkomunikasi sehingga manusia dan bahasa adalah dua hal yang tidak dapat dipisahkan satu dengan yang lain. Dalam hidup manusia selalu membutuhkan manusia lain. Oleh karena itu, manusia membutuhkan bahasa sebagai alat dalam menjalin komunikasi dengan manusia lain.

Bahasa Indonesia sudah terjadi pada saat memperoleh bahasa pertama. Dengan demikian, komunikasi yang terdapat pada bahasa ke dua memiliki campuran kode bahasa. Akan tetapi, dalam Percampuran kode bahasa ini menggunakan bahasa B3 dalam komunikasi antar masyarakat dengan menggunakan kode lain untuk berkomunikasi antarsesama manusia. Dampak dari percampuran kode ini menyebabkan serbuan bahasa-bahasa daerah dan bahasa asing ke dalam pengunaan bahasa sehari-hari. Dengan kondisi yang demikian, proses komunikasi dalam dwibahasa ini terdapat istilah bilingulisme.

Istilah biligualisme penggunaan bahasa Indonesia sudah terjadi pada saat memperoleh bahasa pertama. Sehubungan dengan itu, seseorang yang sedang berkomunikasi dengan orang lain tanpa disadari terdapat penggunaan sisipan bahasa lain ke dalam komunikasi tersebut. oleh karena itu, peristiwa ini disebut dengan campur kode. Campur kode dua bahasa yang disisipkan ke dalam komunikasi dengan orang lain yang disebabkan oleh penutur yang sudah memahami bahasa pertama atau B1.

Chaer (2012: 69) menyatakan bahwa dalam campur kode ini dua kode atau lebih digunakan bersama tanpa alasan dan biasanya terjadi dalam situasi santai. Dengan demikian, campur kode biasanya karena ketiadaan ungkapan yang harus digunakan dalam bahasa yang dipakai. Oleh karena itu, campur kode biasanya dalam berbicara bahasa Indonesia tercampur dengan unsur-unsur bahasa daerah yang digunakan dalam berkomunikasi.

Campur kode merupakan unsur-unsur yang menyebabkan terjadinya campur kode ke dalam sebuah kalimat inti. Achmad dan Abdullah (2013: 159) mendefinisikan bahwa campur kode peristiwa penggunaan dua buah kode bahasa atau lebih oleh penutur, di mana salah satu kode yang digunakan hanya berupa serpihan kata (partikal leksikal), kata, frase, atau juga klausa satu bahasa lain dalam satu situasi. Dengan demikian, definisi ini merujuk pada wujud campur kode yang berupa kata, frase, atau dengan klausa.

Lynch (dalam Hernimawati, 2018 :1-2) menyatakan bahwa reklame dapat digunakan sebagai salah satu alat komunikasi visual dalam lingkungan perkotaan dengan menggunakan tanda atau signage. Pemasangan reklame, selain pada bangunan juga pada ruang terbuka. Pemasangan reklame pada berbgai lokasi dilakukan oleh berbagai pihak dengan tujuan mempromosikan sesuatu. Dengan demikian, papan reklame yang digunakan dalam membuat iklan berupa tanda yang menunjukan kepemilikan status, barang, dan jasa.

Papan reklame yang digunakan dalam membuat iklan berupa tanda yang terdapat pada jalan-jalan raya untuk menarik minat konsumen sehingga 
banyaknya perusahaan menggunakan papan reklame menjadikan iklan untuk memudahkan konsumen dalam berkomunikasi antar perusahaan yang membuat iklan.

Iklan merupakan alat untuk memberikan informasi sebuah produk atau menawarkan jasa sehingga banyaknya perusahaan menggunakan iklan sebagai alat untuk menawarkan produk atau jasa dalam bentuk iklan. Madjadikara (2005: 17) menyatakan bahwa iklan komersial adalah iklan yang bertujuan mendukung kampanye pemasaran suatu produk atau jasa. Iklan komersial yang dimuat atau disiarkan melalui media audio (radio) atau audio visual (televisi). Dengan demikian, iklan komersial merupakan alat untuk menawarkan jasa atau produk untuk ditawrkan kepada konsumen melalui media.

Hoed (2001: 98) mengungkapkan bahwa iklan komersial adalah yang bersifat menjual produk atau jasa dengan tujuan agar produk atau dibeli oleh sasaran iklan, dengan tujuan memperoleh keuntungan. Dengan demikian bahwa iklan komersil merupakan tujuan untuk menggambarkan secara sistematis produk yang akan dijual. Oleh sebab itu, iklan bertujuan untuk dilihat oleh masyarakat sehingga jika ada masyarakat melihat iklan tersebut dapat membeli produk yang diiklankan.

Merujuk uraian di atas, dapat diketahui bahwa campur kode dapat masuk pada sebuah iklan. Salah satunya iklan komersial. Hal ini menarik untuk diteliti karena sebagai pengguna bahasa kita akan dihadapkan pada sebuah realita di masyarakat terkait pada iklan-iklan yang banyak menggunakan campur kode. Oleh karena itu, perlu adanya penelitian terkait dengan hal tersebut.

\section{METODE}

Pendekatan yang digunakan dalam penelitian ini adalah deskriptif kualitatif. Wibowo (2011: 43) mengungkapkan bahwa deskriptif-kualitatif adalah penggambaran secara kualitatif fakta, data, atau objek material yang bukan berupa rangkaian angka, melainkan berupa ungkapan bahasa atau wacana (apa pun itu bentuknya) melaui interpretasi yang tepat dan sistematis. Oleh sebab itu, deskriptif kualitatif membuang jauh-jauh hipotesis dan asumsi mengubahnya menjadi "perumusan masalah", yakni dalam rangka menjelaskan fenomenafenomena secara praktis atau dalam rangka menyusun atau merumuskan teori, prinsip konsep, atau pengetahuan baru berdasarkan data yang dikumpulkan oleh peneliti.

Metode yang digunakan yaitu metode survei dengan teknik analisis isi. Sumber data pada penelitian ini yaitu iklan-iklan komersial yang terdapat di Sepanjang Jalan Raya Bogor, Jawa Barat.

\section{HASIL DAN PEMBAHASAN}

\section{Hasil}


Diskursus: Jurnal Pendidikan Bahasa Indonesia

Vol. 4, No. 1, April 2021, pp. 9-18 p-ISSN: 2615-4935 e-ISSN: $2615-4943$

Berdasarkan hasil analisis data yang telah dilakukan, diperoleh temuantemuan sebagai berikut.

Tabel 1. Rekapitulasi Hasil Temuan Wujud Campur Kode

\begin{tabular}{ccccc}
\hline No & & Wujud campur kode & Jumlah & Persentase \\
\hline 1. & Kata & & 22 & $42.3 \%$ \\
2. & Frasa & & 21 & $40.4 \%$ \\
3. & Klausa & 9 & $17.3 \%$ \\
& & Total Keseluruhan & 52 & $100 \%$ \\
& & & & \\
\hline
\end{tabular}

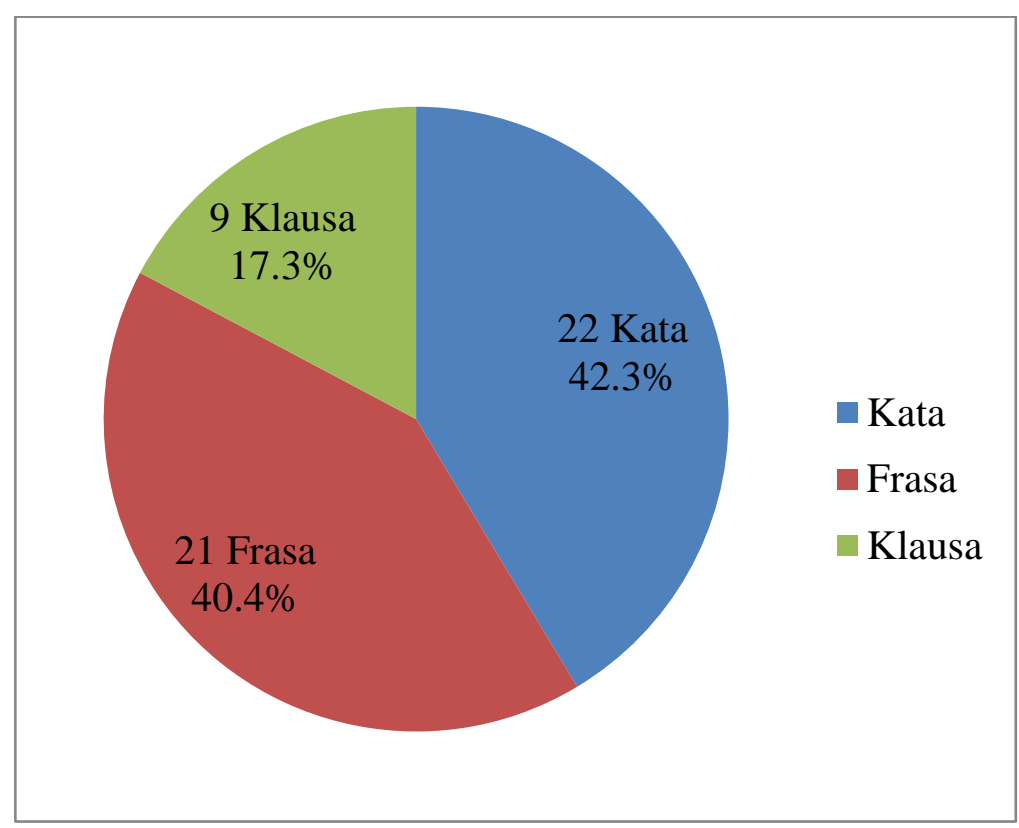

\section{Diagram 1. Rekapitulasi Temuan}

Berdasarkan tabel dan diagram temuan, tampak wujud campur kode pada papan reklame iklan komersial dengan hasil survei di Sepanjang Jalan Raya Bogor, Jawa Barat terdapat 22 kata, 21 frasa, dan 9 klausa. Dalam hal ini, penggunaan kata lebih dominan digunakan yaitu sebanyak 22 kata dengan hasil persentase sebanyak $42,3 \%$. 


\section{Diskursus: Jurnal Pendidikan Bahasa Indonesia}

Vol. 4, No. 1, April 2021, pp. 9-18

p-ISSN: 2615-4935

e-ISSN: 2615-4943

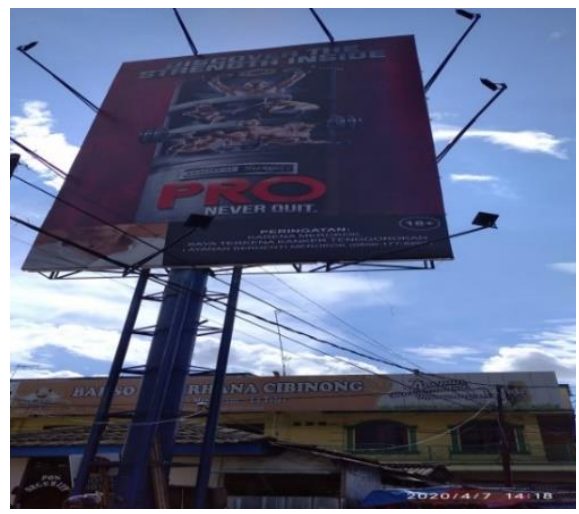

Gambar 1. Iklan Rokok Surya Pro

Kalimat:

Discover the strength inside quality of surya pro, never quit, 18+, peringatan: karena merokok saya terkena kanker tenggorokan, layanan berhenti merokok (0800-177-6565).

\section{Analisis}

Dalam kalimat iklan rokok surya pro tersebut menggunakan bahasa Indonesia. Akan tetapi, dalam penggunaan kalimatnya ditemukan campur kode berbentuk frasa dan klausa, yaitu pada kata "discover the strength inside quality of" dan kata "never quit". Kata-kata tersebut berasal dari bahasa Inggris, bentuk klausa yang berarti "temukan kekuatan di dalam kualitas surya"dan bentuk frasa yang berarti "tidak pernah berhenti". Dapat diketahui dalam teori Achmad dan Abdullah (2013: 159) bahwa campur kode merupakan peristiwa penggunaan dua buah kode bahasa atau lebih oleh penutur, di mana salah satu kode yang digunakan berupa (partikal leksikal), kata, Frasa atau juga klausa satu bahasa lain dalam satu situasi. Dengan demikian, dapat disimpulkan bahwa kata "never quit" dan "discover the strength inside quality of" termasuk dalam bentuk frasa dan klausa yang merupakan wujud campur kode satu bahasa lain dalam satu situasi.

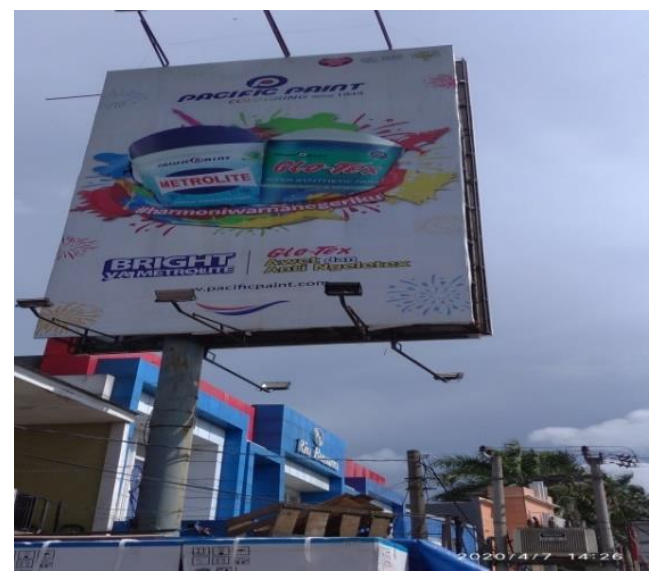

Gambar 2. Iklan Cat Pacific Paint

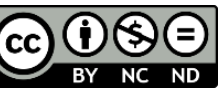


Kalimat:

Pacific paint, colouring since 1943, Pacifific paint, metrolite, acrylic emulsion paint, Pacifific paint, super synthetic paint, cat kayu dan besi, \#harmoniwarnanegeriku!, bright ya metrolite, Glo-tex,awet dan anti ngeletek.

\section{Analisis}

Dalam kalimat iklan cat pacific paint tersebut menggunakan bahasa Indonesia. Akan tetapi, dalam penggunaan kalimatnya ditemukan campur kode berbentuk frasa dan kata, yaitu pada kata "colouring since", "acrylic emulsion paint", "synthetic paint" dan kata "bright". Kata-kata tersebut berasal dari bahasa Inggris, bentuk frasa yang berarti "mewarnai sejak", "cat emulsi akrilik", "cat sintetis" dan bentuk kata yang berarti "terang". Dapat diketahui dalam teori Achmad dan Abdullah (2013: 159) bahwa campur kode merupakan peristiwa penggunaan dua buah kode bahasa atau lebih oleh penutur, dimana salah satu kode yang digunakan berupa (partikal leksikal), kata, Frasa atau juga klausa satu bahasa lain dalam satu situasi. Dengan demikian dapat disimpulkan bahwa kata "colouring since", "acrylic emulsion paint", "synthetic paint" dan kata "bright" termasuk dalam bentuk frasa dan kata yang merupakan wujud campur kode satu bahasa lain dalam satu situasi.

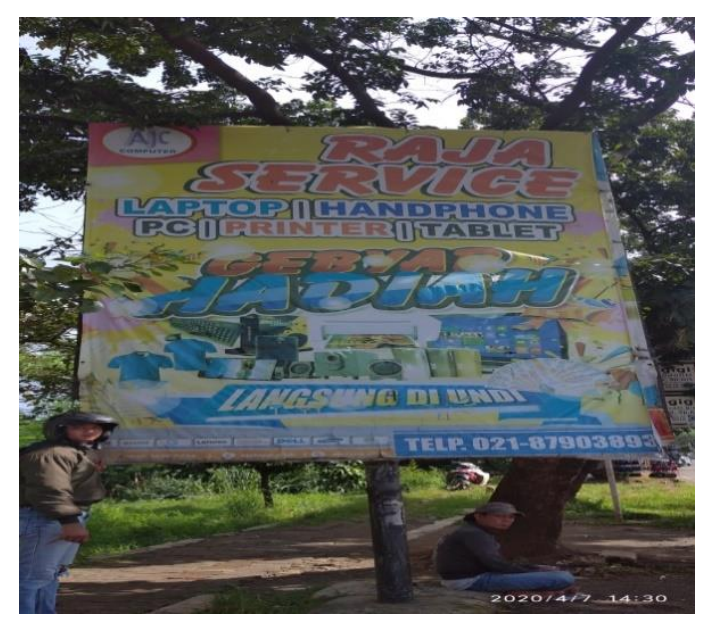

\section{Gambar 3. Iklan Servis elektronik}

Kalimat:

Raja service, laptop, handphone, PC, printer, tablet, gebyar hadiah, langsung diundi, telp. 021-87903893.

\section{$\underline{\text { Analisis }}$}

Dalam kalimat iklan Servis elektronik tersebut menggunakan bahasa Indonesia. Akan tetapi, dalam penggunaan kalimatnya ditemukan campur kode berbentuk kata, yaitu pada kata "service" dan "handphone". Kata-kata tersebut berasal dari bahasa Inggris, bentuk kata yang berarti "servis" dan "gawai". Dapat diketahui dalam teori Achmad dan Abdullah (2013: 159) bahwa wujud campur kode peristiwa penggunaan dua buah kode bahasa atau lebih oleh penutur, di mana 


\section{Diskursus: Jurnal Pendidikan Bahasa Indonesia}

Vol. 4, No. 1, April 2021, pp. 9-18

p-ISSN: 2615-4935

e-ISSN: 2615-4943

salah satu kode yang digunakan berupa (partikal leksikal), kata, Frasa atau juga klausa satu bahasa lain dalam satu situasi. Dengan demikian dapat disimpulkan bahwa kata "service" dan "handphone" termasuk dalam bentuk kata yang merupakan wujud campur kode satu bahasa lain dalam satu situasi.

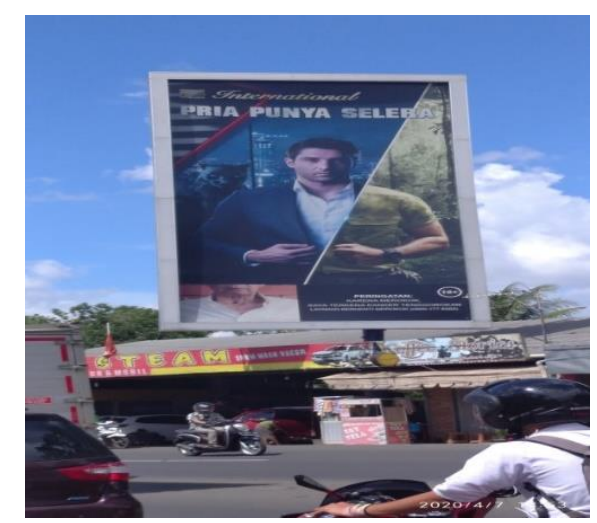

\section{Gambar 4. Iklan Rokok Gudang Garam}

Kalimat:

Gudang garam International, pria punya selera, 18+, peringatan: karena merokok saya terkena kanker tenggorokan, layanan berhenti merokok (0800-177-6565).

\section{$\underline{\text { Analisis }}$}

Dalam kalimat iklan rokok gudang garam tersebut menggunakan bahasa Indonesia. Akan tetapi, dalam penggunaan kalimatnya ditemukan campur kode berbentuk kata, yaitu pada kata "International". Kata tersebut berasal dari bahasa Inggris, bentuk kata yang berarti "internasional". Dapat diketahui dalam teori Achmad dan Abdullah (2013: 159) bahwa wujud campur kode peristiwa penggunaan dua buah kode bahasa atau lebih oleh penutur, dimana salah satu kode yang digunakan berupa (partikal leksikal), kata, Frasa atau juga klausa satu bahasa lain dalam satu situasi. Dengan demikian dapat disimpulkan bahwa kata "International" termasuk dalam bentuk kata yang merupakan wujud campur kode satu bahasa lain dalam satu situasi.

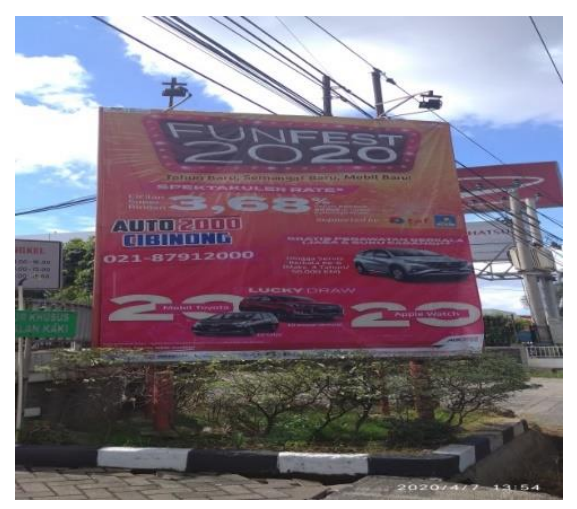

Gambar 5. Iklan AUTO 2000

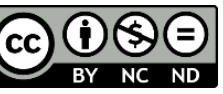


Kalimat:

Funfest 2020, tahun baru, semangat baru, mobil baru, spektakuler rate, cicilan super ringan, 3,68\%, include asuransi all risk di toyota autrized dealer, supported by: taf, auto 2000 cibinong 021-87912000, gratis perawan berkala(jasa \& suku cadang), hingga servis berkalake-6(maks. 4 tahun/50.000 KM), lucky draw,20 mobil toyota, 20 apple watch.

\section{Analisis}

Dalam kalimat iklan auto 2000 Cibinong tersebut menggunakan bahasa Indonesia. Akan tetapi, dalam penggunaan kalimatnya ditemukan campur kode berbentuk frasa dan kata, yaitu pada kata "all risk", "autrized dealer", "supported by" dan kata "rate", "include", "lucky draw". Kata-kata tersebut berasal dari bahasa Inggris, bentuk frasa yang berarti "semua resiko", "dealer resmi", "didukung oleh" dan bentuk kata yang berati "menilai", "termasuk", "undian". Dapat diketahui dalam teori Achmad dan abdullah (2013: 159) bahwa campur kode merupakan peristiwa penggunaan dua buah kode bahasa atau lebih oleh penutur, dimana salah satu kode yang digunakan berupa (partikal leksikal), kata, Frasa atau juga klausa satu bahasa lain dalam satu situasi. Dengan demikian dapat disimpulkan bahwa kata "all risk", "autrized dealer", "supported by" dan kata "rate", "include", "lucky draw" termasuk dalam bentuk frasa dan kata yang merupakan wujud campur kode satu bahasa lain dalam satu situasi.

\section{Pembahasan}

Berdasarkan hasil penelitian yang telah dilakukan terhadap papan reklame iklan komersial dengan survei di sepanjang Jalan Raya Bogor, Jawa Barat, terbukti bahwa terdapat penggunaan bahasa asing yang dalam pembuatan iklan tersebut. Dengan demikan, papan reklame yang ditempatkan di sepanjang jalan tersebut banyak menggunakan bahasa asing.

Peristiwa campur kode merupakan dari bahasa asli yang disisipi oleh bahasa daerah di dalam tiga bentu campur kode yaitu: kata, frasa, dan klusa. seperti yang dikemukakan Wakhidah dan Sudaryanto (2019: 275), "wujud terjadinya campur kode ada lima yaitu: kata, kelompok kata, baster, kata ulang, klausa. Pengertian tersebut mempunyai arti bahwa campur kode penggunaaan dari bahasa asli oleh bahasa daerah yang disisipi kata, kelompok kata, baster, kata ulang, klausa di dalamnya.

Campur kode peristiwa penggunaan dua buah bahasa atau lebih oleh penutur dengan menyisipkan bahasa asing di dalamnya berupa serpihan kata, frasa, dan kalusa kata, frasa, dan klausa. seperti yang dikemukakan Wirahyuni (2017: 158), "campur kode terjadi apabila suatu bahasa secara dominan mendukung suatu tuturan disiipi degan unsurn bahasa lainnya dalam lima bentuk yaitu: penyisipan kata, penyisipan kelompok kata, penyisipan baster, penyisipan ungkapan atau idiom, dan penyisipan klausa. Pengertian tersebut mempunyai arti bahwa campur kode penggunaaan dua bahasa atau lebih dengan menyisipkan unsur bahasa lainnya ke dalam bentuk kata, baster, kata ulang, idiom, dan klausa dalam satu situasi. 
Hasil penelitian ini pun sejalan dengan penelitian Hafari (2015) yang berjudul "Analisis Campur Kode dalam Iklan Radio Citra FM Kabupaten Wonosobo pada Bulan April 2015" yakni menemukan bahwa pada iklan ini memiliki peristiwa campur kode dalam wujud kata terbanyak sehingga memberikan wujud frasa dan klausa rendah dalam penelitiannya. Hal ini membuktikan bahwa tingkat penggunaan campur kode dalam iklan, secara signifikan memengaruhi tingkat penggunaan bahasa yang baik khususnya dalam wujud kata.

Campur kode terjadi apabila beberapa alasan yang bersumber dari penutur bahasa asli dengan menyisipkan bahasa asing di dalamnya berupa berupa kata, frasa, dan kalusa. Seperti yang dikemukakan Ferawati (2019) "percampuran dua atau lebih bahasa atau ragam bahasa dalam suatu tindak tutur tanpa ada sesuatu dalam situasi berbahasa yang menuntut percampuran bahasa itu, wujud campur kode ada empat yaitu, kata, frasa, klausa, dan kalimat". Pengertian tersebut mempunyai arti bahwa campur kode penggunaaan dari bahasa asli oleh bahasa daerah yang disisipi kata, frasa, klausa, dan kalimat di dalamnya.

Campur kode terjadi apabila beberapa alasan yang berasal dari penutur yang ingin mentafsirkan atau menjelaskan, dalam campur kode berupa kata, frasa, dan kalusa. Hal ini senada dengan Marlin (2018) "caampur kode terjadi karena adanya hubungan timbal balik antara peranan penutur, bentuk bahasa, dan dunsi bahasa, bebearapa bentuk wujud campur kode tiga ada yaitu: kata, frasa, dan klausa Pengertian tersebut mempunyai arti bahwa campur kode terjadi antara peranan penutur dari bahasa asli oleh bahasa daerah yang disisipi kata, frasa, klausa, di dalamnya.

Dalam penelitian ini, dari data yang ditemukan diklasifiaksikan dalam bentuk campur kode yang digunakan berupa kata, frasa dan klausa pada papan reklame iklan komersial. Oleh karena itu, pada penlitian ini bahwa campur kode merupakan penggunaaan dari bahasa asli oleh bahasa daerah yang disisipi berupa kata, frasa, dan klausa di dalamnya.

\section{SIMPULAN}

Berdasarkan hasil dan pembahasan, dapat disimpulkan bahwa wujud campur kode terbanyak dalam penelitian ini berupa kata. Hal ini memberi gambaran terkait unsur kata lebih banyak ditemukan pada papan reklame. Oleh karena itu, tidak dapat dipungkiri, penggunaan bahasa asing, khususnya campur kode pada papan reklame menjadi daya tarik tersendiri dalam beriklan.

\section{DAFTAR PUSTAKA}

Achmad, HP., \& Abdullah, A. (2013). Linguistik umum. Jakarta: Erlangga Chaer, A. (2012). Linguistik umum. Jakarta: Rineka Cipta. 
Ferawati. (2019). Campur kode pada acara "Rumah Uya" di Trans 7. Jurnal Bahasa dan Sastra, 4(1): 32-43. http://jurnal.untad.ac.id/jurnal/index.php/ BDS/article/view/12252

Hafari, A.I. (2015). Analisis campur kode dan alih kode dalam iklan radio Citra FM Kabupaten Wonosobo pada Bulan April 2015. Jurnal Program Studi Pendidikan Bahasa dan Sastra Jawa, 07(01): 74-82. http://ejournal. umpwr.ac.id/index.php/aditya/article/view/2404

Hernimawati. (2018). Model implementasi kebijakan penataan reklame. Surabaya: Jakad Publishing.

Hoed, B. H. (2001). Dari logika tuyul ke erotisme. Magelang: Yayasan Indonesiatera Anggota IKAPI.

Madjadikara, S. A. (2005). Bagaimana biro iklan memproduksi iklan bimbingan praktis penulisan naskah iklan. Jakarta: gramedia Pustaka Utama.

Marlin. (2018). Campur kode caramah Ustad Maulana dalam Acara "Islam Itu Indah" di Trans TV. Jurnal Bahasa dan Sastra, 3(1): 1-13. http://jurnal. untad.ac.id/jurnal/index.php/BDS/article/view/10040

Wakhidah, S., \& Sudaryanto. (2019). Analisis campur kode dalam iklan daring Lazada Edisi April 2019: Kajian Sosiolinguistik. Deiksis, 11(03): 269-375. https://journal.lppmunindra.ac.id/index.php/Deiksis/article/view/3852

Wibowo, W. (2011). Cara cerdas menulis artikel ilmiah. Jakarta: Kompas Media Nusantara.

Wirahyuni, K. (2017). Campur Kode dalam Iklan di Radio dan Televisi. Jurnal IKA, 15 (2) 157-167. https://ejournal.undiksha.ac.id/index.php/IKA/article /view/20193 